\title{
Lipid Level of Street Food at Cibeusi Elementary School in Jatinangor Subdistrict, West Java, Indonesia
}

\author{
Siti Nur Fatimah, ${ }^{1}$ Indri Nurul Hayyi, ${ }^{2}$ Adria Adnan ${ }^{3}$ \\ ${ }^{1}$ Department of Public Health Faculty of Medicine Universitas Padjadjaran, ${ }^{2}$ Faculty of Medicine \\ Universitas Padjadjaran, ${ }^{3}$ Department of Biomedical Sciences Faculty of Medicine Universitas \\ Padjadjaran
}

\section{Abstract}

Background: School-aged children have quite high energy consumption demand because they are growing and physically active. In Indonesia, school-aged children frequently consume their additional foods/snacks from street food vendors around their schools. This study aimed to reveal the lipid level of street food in Elementary Schools, in Jatinangor Subdistrict, West Java, Indonesia.

Methods: This study was an observational descriptive study. Elementary Schools in Jatinangor Subdistrict were selected using a random sampling method. Four frequent street foods were fried meatball (in Indonesian: bakso goreng (basreng)), batagor (bakso tahu goreng), crepes, and egg roll were then taken, and lipid level was measured twice using Soxhlet extraction method.

Results: Fried meatball contained $22.10 \%( \pm 0.23 \%)$ or 2.78 gram lipid, batagor $30.091 \%( \pm 4.14 \%)$ or 12.49 gram lipid, crepes $7.14 \%( \pm 0.12 \%$ ) or 0.66 gram lipid, and egg roll $13.66 \%( \pm 1.63 \%)$ or 1.28 gram lipid.

Conclusions: Only the batagor fulfilled the lipid demand in one snack time. It is recommended to minimize the intake of batagor as a between-meal snack for a balanced nutrient intake control.

Keywords: Lipid level, Soxhlet extraction, street food

\section{Introduction}

School-aged children have quite high energy consumption demand as well as their need for food because they are growing and active physically. ${ }^{1,2}$ Children tend to eat small amounts of food frequently throughout the day because the stomach capacity is small. To overcome the high total calorie requirements, they should have more meal servings, therefore, additional food or snacks are considered necessary. Additional food or snacks provide additional energy in 2 hours after a meal, so their body can remain fulfilling the nutritional requirements. It is good to give the schoolaged children additional food or snacks twice a day between the main meal, in mid-morning and mid-afternoon., ${ }^{3,4}$ Street foods are readyto-eat food and beverages prepared and/or sold by vendors and hawkers especially in the streets or other similar public places. ${ }^{5}$
Children have different nutrition necessities based on age and gender. Seven to nine years old children need 45 gram protein and 1800 kcal energy per day. Ten to twelve years old children need 50 gram protein and $2050 \mathrm{kcal}$ energy per day. ${ }^{6}$ The emphasized snacks are foods which contain 300 kcal energy and 5 gram protein or provide $10-20 \%$ energy and protein for everyone in a day. ${ }^{7,8}$

Additional food or snack consumption would meet $23 \%, 21.7 \%$, and $30 \%$ of total daily energy, protein, and fat requirements, respectively. ${ }^{9}$ Those are considered higher than the total daily requirements themselves, especially in fat consumption. In Indonesia, it is common that school-aged children frequently consume additional food or snacks from street food vendors around their schools. This study aimed to reveal the lipid level of street food in an Elementary School, Jatinangor Subdistrict, Sumedang, West Java, Indonesia.

Correspondence: Siti Nur Fatimah, Department of Public Health, Faculty of Medicine, Universitas Padjadjaran, Jalan Raya Bandung-Sumedang Km.21, Jatinangor, Sumedang, Indonesia, E-mail: st_nurf@yahoo.com 


\section{Methods}

This descriptive observational study was conducted by taking some samples of street food from elementary school in the Jatinangor subdistrict, Sumedang Regency, West Java Province, Indonesia in September 2013. The school was selected by using a random sampling method. A preliminary survey was implemented by using an interview approach to reveal the most commonly consumed type of foods in that school.

Of each sample, the lipid level was measured in duplo directly by the soxhlet extraction method. Lipid was extracted from an organic solvent, diethyl eter, by refluxing at a temperature that was suitable with the boiling point of the solvent used. In brief, the chosen snack had been dried and refined, before encased with filter paper. The filter paper that contained the sample was inserted into the Soxhlet equipment. On top of it, condenser had been installed and on the bottom of it, a flask was placed, which contained solvent. Reflux was then conducted for five hours until the solvent descended back into a flask. During reflux, the solvent would evaporate and dissolve fat in the sample. Furthermore, the fat would enter into a flask. The flask containing the fat of extraction result was heated in the oven at $150^{\circ} \mathrm{C}$, until its weight was constant. After the flask was cooled, the fat weight was weighted.

Some factors such as particle size, type of solvent, duration of extraction, and temperature of extraction could influence the Soxhlet method analysis result. The smaller particle size resulted in greater total particle surface that exposed to the solvent, the faster and more efficient the extraction process could occur. The Lipophylic solvent was the best type of solvent because of its compatibility with the sample's lipid component and thus produced a better extraction result. The longer the duration of extraction, the more soluted lipid the Soxhlet extraction could produce, so there was nearly no residual sample to be found. This process of extraction must be performed at a suitable temperature that was compatible with the solvent evaporating point. ${ }^{10}$

After conducting Soxhlet extraction, lipid level of the foods was calculated by using this formula:

$$
\% \text { lipid }=\frac{W c-W a}{W b} \times 100
$$

Note: Wc=pre-distilled flask weight, Wa=distilled flask weight, $\mathrm{Wb}=$ sample weight

\section{Results}

Before the study started, a survey was established to explore the most commonly consumed type of food. From fourteen that were available and sold in the school, five foods were listed as the most consumed type of food, including fried meatballs (in Indonesian: bakso goreng (basreng), batagor (bakso tahu goreng), crepes, egg roll, and sandwich. Only basreng, batagor, crepes and egg roll were further included in this study since the sandwich vendor did not appear during the sampling.

Of the four types of street food that were the most frequently eaten by the school children in elementary school in Jatinangor subdistrict, batagor had the highest lipid level compared to other street food which was 30.091 percent $( \pm 4.14 \%)$ or 12.49 gram lipid (Table 1$)$.

\section{Discussion}

Soxhlet extraction is a lipid-level measurement for solid material, including a solid food sample that uses lipid soluting phenomenon

Table 1 Lipid Level of Street Food at Cibeusi Elementary School

\begin{tabular}{lcccc}
\hline Street food & $\begin{array}{c}\text { Sample Weight } \\
\text { (gram) }\end{array}$ & $\begin{array}{c}\text { Lipid Level } \\
\text { (\%) }\end{array}$ & $\begin{array}{c}\text { Sample Weight per } \\
\text { portion } \\
\text { (gram) }\end{array}$ & $\begin{array}{c}\text { Lipid Weight per } \\
\text { Portion } \\
\text { (gram) }\end{array}$ \\
\hline Basreng & 2.96 & 22.10 & 37.35 & 2.78 \\
Batagor & 2.65 & 30.91 & 107.25 & 12.49 \\
Crepes & 2.81 & 7.14 & 25.95 & 0.66 \\
Egg roll & 2.87 & 13.66 & 26.90 & 1.28 \\
Average & & 18.89 & 49.36 & 4.30 \\
\hline
\end{tabular}

Note: Fried meatball or bakso goreng (basreng); batagor (bakso tahu goreng). The Lipid level was average of duplo measurement 
by evaporating solvent. There are some solvent for Soxhlet extraction that can be used, for example, hexane and diethyl ether. Our study has used hexane as a solvent because of its non-flammable property and cheapness. ${ }^{10}$

The Duplo process, in which lipid level measurement was performed twice, was conducted in each of the samples. The measurement had two different results. As had been explained before, there were some factors such as particle size, type of solvent, duration of extraction, and temperature of extraction that could influence Soxhlet method analysis result. ${ }^{10}$

This study revealed that batagor had the highest result with $30.91 \%$ average and crepes had the lowest one, $7.14 \%$ average. These two foods differed in their ingredients and processing. One portion of basreng contained 2.78 grams of lipid, batagor contained 12.49 gram of lipid, crepes contained 0.66 grams of lipid, and egg roll contained 1.28 grams of lipid. The results can be compared to The Guidance on Additional Food for School-Aged Children Serving in 2012 (in Indonesian: Pedoman Penyediaan Makanan Tambahan Anak Sekolah 2012), which suggested that each child should consume additional food or snacks containing $300 \mathrm{kcal}$ of energy and 5 grams of protein distributed in two snack times. Lipid and Carbohydrate should contain $75 \mathrm{kcal}$ and 180 kcal of energy every day. In one snack time, the snack should contain $37.5 \mathrm{kcal}$ of energy from lipid or equals to 4.16 grams of lipid..$^{11}$

Daily lipid dietary consumption should not comprise over 25 percent of total daily energy needs. ${ }^{12}$ Excessive lipid consumption can lead to obesity and increase the risk of vascular and heartdisease in thefuture. However, insufficient daily lipid consumption can also give rise to health problems, for example, failure to thrive, vitamin and mineral absorption disorder, and immune disorder. ${ }^{13,14}$ A study conducted in on $4^{\text {th }}$ and $5^{\text {th }}$ graders elementary school in Bogor has revealed that additional food or snack consumption in school-aged children exceeded daily nutritional needs. ${ }^{9}$ This study has shown that about $23 \%$ of energy needs $21.7 \%$ of total protein need, and $30 \%$ of total fat need have to be fulfilled by consuming the additional food or/snacks alone.

Some factors would be considered as limitations of this study. The Soxhlet extractor apparatus used in this study could not interpret the sensitivity and specificity values because it has measured processed food instead of pure lipid solution. Human error such as non-homogenous sample because unevenly mashed and unclean flask contaminated by human skin fat may also interfere with the result of lipid level measurement.

This study concluded that the lipid level in a portion of batagor fulfilled the lipid demand in one snack time. Education for the students needs to be given on how to select safe street foods. Furthermore, healthy canteens at school need to be considered to provide more healthy food.

\section{Acknowledgment}

We are grateful to elementary school in Cibeusi Elementary School for collaboration in this study.

\section{References}

1. Kusmandayu T, Muniroh L. Relationship between the level of knowledge and street food consumption patterns with nutritional status of children. International Proceedings of Chemical, Biological and Environmental Engineering. 2012;39:304.

2. Hariyadi D, Damanik MR, Ekayanti I. Analisis hubungan penerapan pesan gizi seimbang keluarga dan perilaku keluarga sadar gizi dengan status gizi balita di provinsi Kalimantan Barat. Jurnal Gizi dan Pangan. 2010;5(1):61-8.

3. Soetrisno US, Almasyhuri, Karyadi L. Pengaruh makanan tambahan glikemik tinggi terhadap peningkatan konsentrasi belajar siswa sekolah dasar. Penel Gizi Makan. 2005;28(2):83-91.

4. Loubna B, Nacer AA. Food and nutrition education; elaboration of a guide for children of 6 to 12 years. Int J Nutr Metab. 2012;4(1):1-10.

5. Khairuzzaman M, Chowdhury FM, Zaman S, Al Mamun A, Bari ML. Food safety challenges towards safe, healthy, and nutritious street foods in Bangladesh. Int J Food Sci. 2014;2014:483519.

6. Menteri Kesehatan Republik Indonesia. Keputusan Menteri Kesahtan Republik Indonesia Nomor 1593/Menkes/SK/ XI/2005 tentang Angka Kecukupan Gizi yang dianjurkan bagi orang Indonesia. Jakarta: Kementerian Kesehatan Republik Indonesia; 2005.

7. Temple JL, Bulkley AM, Badawy RL, Krause N, McCann S, Epstein LH. Differential effects of daily snack food intake on the reinforcing value of food in obese and nonobese women. Am J Clin Nutr. 
2009;90(2):304-13.

8. Lachat C, Khanh LNB, Khan NC, Dung NQ Anh NDV, Roberfroid D, et al. Eating out of home in Vietnamese adolescents: socioeconomic factors and dietary associations. Am J Clin Nutr. 2009;90(6):1648-55.

9. Syafitri Y, Syarief H, Baliwati YF. Kebiasaan jajan siswa sekolah dasar (studi kasus di SDN Lawanggintung 01 kota Bogor). Jurnal Gizi dan Pangan. 2009;4(3):167-75.

10. Blum-Fretz C, Baumann A, Feifel S. Fat determination: Comparison between Soxhlet and Hot Extraction using the Extraction Units E-812/E-816. best@ buchi: Information Bulletin: 2007;47:1-8.

11. Direktorat Pendidikan Madrasah Ditjen Pendidikan Islam. Pedoman pelaksanaan penyediaan makanan tambahan anak sekolah (PMT-AS) bagi siswa RA dan MI tahun 2012. Jakarta: Kementerian Agama Republik Indonesia; 2012

12. Zhang J, Hebert JR, Muldoon MF. Dietary fat intake is associated with psychosocial and cognitive functioning of schoolaged children in the United States. J Nutr. 2005;135(8):1967-73.

13. Hendriksen MA, Boer JM, Du H, Feskens EJ, Van der A DL. No consistent association between consumption of energy-dense snack foods and annual weight and waist circumference changes in Dutch adults. Am J Clin Nutr. 2011;94(1):19-25.

14. St-Onge MP, Aban I, Bosarge A, Gower B, Hecker KD, Allison DB. Snack chips fried in corn oil alleviate cardiovascular disease risk factors when substituted for low-fat or high-fat snacks. Am J Clin Nutr. 2007;85(6):1503-10. 